\title{
Evaluation of different IPM modules against ber stone weevil, Aubeus himalayanus in hot arid region of India
}

\author{
SM Haldhar, AK Singh \& DK Sarolia
}

Journal of Agriculture and Ecology

ISSN: 2456-9410

Volume: 11

Journal of Agriculture and Ecology (2021) 11: 69-77 http://doi.org/10.53911/JAE.2021.11108

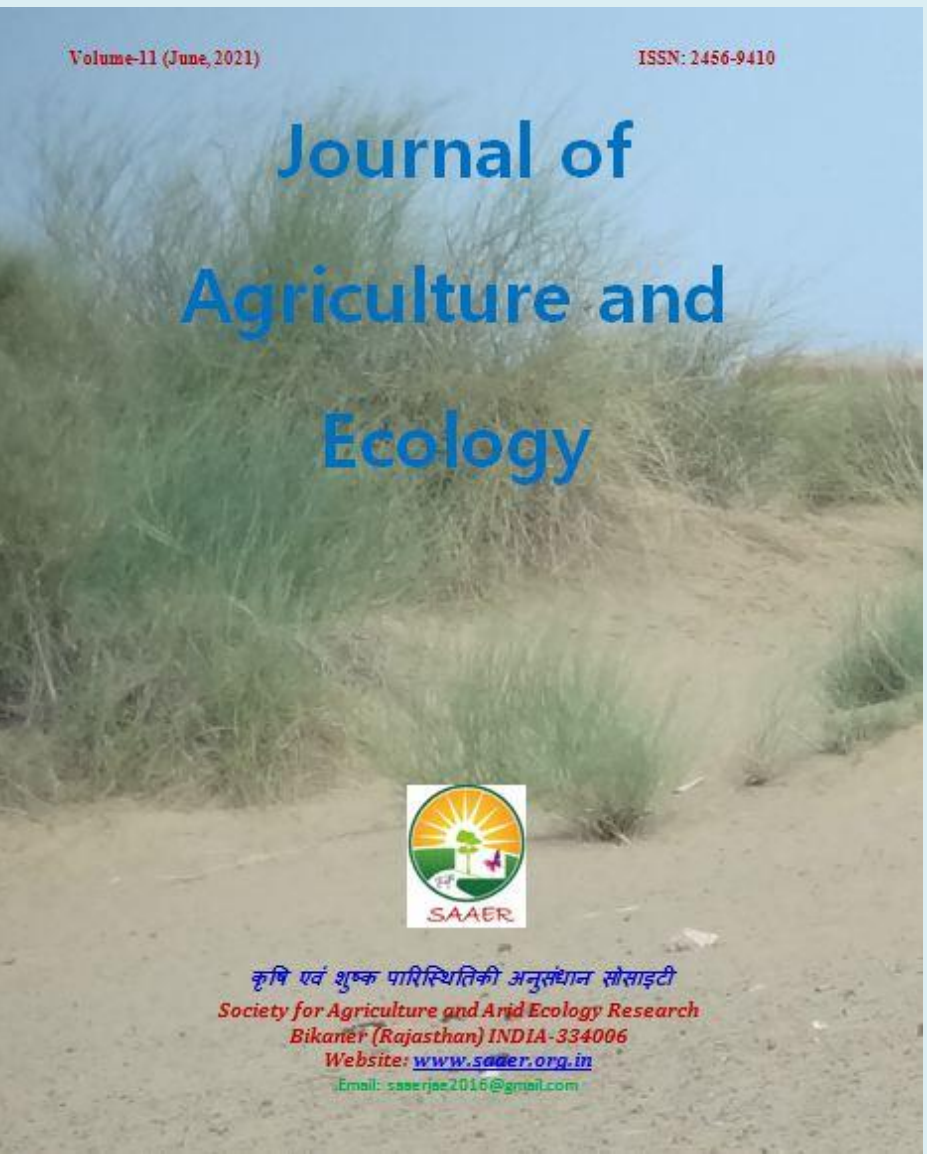


Evaluation of different IPM modules against ber stone weevil, Aubeus himalayanus in hot arid region of India

\author{
SM Haldhar ${ }^{1 \& 3} \not$, AK Singh ${ }^{2} \&$ DK Sarolia ${ }^{1}$ \\ ${ }^{1}$ ICAR-Central Institute for Arid Horticulture, Sri Ganganagar Highway, Beechwal Industrial Area, \\ Bikaner (Rajasthan) 334006 \\ ${ }^{2}$ Central Horticultural Experiment Station (ICAR-CIAH), Godhra-Vadodara Highway, Vejalpur \\ (Gujarat) - 389340, India \\ ${ }^{3}$ (Present Address: Department of Entomology, College of Agriculture (CAU), Iroisemba, Imphal, \\ Manipur 795004) \\ \Corresponding author: SM Haldhar, E-mail: haldhar80@gmail.com
}

\section{Article Info}

Article history

Received: 25 May 2021

Accepted: 26 June 2021

Available online: 30 June 2021
Key Words: Ber, stone weevil, Aubeus himalayanus, IPM modules, hot arid region of India.

Abstract
The ber stone weevil, Aubeus himalayanus Voss (Coleoptera:
Curculionidae) appeared to be an emerging pest reported from various region of India. The stone weevil is an emerging threat for ber production in India especially in Northern India. The results showed that organic IPM module-II registered significantly lower stone weevil population $(12.04 \%$ on retained fruits $\& 15.04 \%$ in dropped fruits) followed by module-I (21.26 $\%$ on plant fruits \& $26.15 \%$ in fallen fruits). The highest stone weevil population was observed under control module $(49.23 \%$ on retained fruits \& $54.91 \%$ in dropped fruits). The marketable yield of ber fruits differed significantly under different modules. The fresh fruit yield of ber was observed in the order of organic IPM module-II $(82.26 \mathrm{~kg} / \mathrm{plant})>$ module-I $(78.25 \mathrm{~kg} /$ plant $)>$ module-IV $(73.14 \mathrm{~kg} /$ plant $)>$ module-III $(64.81 \mathrm{~kg} /$ plant) and least under control module $(56.27 \mathrm{~kg} / \mathrm{plant})$ in pooled both years. It can be inferred from the results that organic IPM module-II (Moderately resistant genotype (Umran), deep summer ploughing after pruning of plants, neem oil spray @ $5 \mathrm{ml}$ per litre of water in October month, hand picking of damaged fruit and adult in November month and spray of spinosad 46 SC (a $0.4 \mathrm{ml}$ per litre of water in December month) was highly effective and gave higher yield of marketable ber fruits. The benefit-cost ratio of the tested ber production systems in the control of stone weevil decreased in the following order: module-II (B: C ratio 10.41:1)> module-I (B: C ratio 9.41:1)> module-IV (B: C ratio 7.08:1)> module-III (B: C ratio 3.66:1).

Copyright (C2021 Haldhar et al., This is an open access article published under the terms of the Creative Commons Attribution License, which permits unrestricted use, distribution, and reproduction in any medium, provided the original work is properly cited.

Preferred citation: Haldhar SM, Singh AK \& Sarolia DK. 2021. Evaluation of different IPM modules against ber stone weevil, Aubeus himalayanus in hot arid region of India. Journal of Agriculture and Ecology, 11: 69-77; http://doi.org/10.53911/JAE.2021.11108.

\section{Introduction}

The ber, Ziziphus mauritiana is native to Province of Yunnan in southern China to
Afghanistan, Malaysia and Queensland, Australia (Morton 1987). It is native of South and Central Asia, found throughout the arid 
and semi-arid tracts. It is cultivated to some extent throughout its natural range on commercial scale and has received much horticultural attention in India (Morton 1987). Z. mauritiana is a gregarious spiny shrub or a small tree, ends of branches curved or drooping. Branches and branchlets armed with short stipular spines. The plant is a vigorous grower and has a rapidly-developing taproot. The richness of the pulp in nutritive compounds has been widely recognized. Nonetheless, there are no definitive values for pulp composition. However ber is richer source of protein, phosphorus, calcium, carotene and vitamin C (Bakhshi \& Singh 1974). The crop is gaining popularity among the growers because of its adaptability to adverse climatic conditions and good returns of yield. The crop is suffered great losses due to insect-pests and diseases (Singh 2008) and more than 130 species of insect-pests were found to attach the crops in India. Balikai (2009) reported a total of 22 insect and noninsect species and likewise, Kavitha \& Savithri (2002) documented about 23 insect species on ber. In addition to these, the ber stone weevil, Aubeus himalayanus Voss (Coleoptera: Curculionidae) appeared to be an emerging pest reported from various region of India (Karuppaiah et al. 2010; Balikai et al. 2013, Haldhar et al. 2012; Haldhar et al. 2016). The stone weevil is an emerging threat for ber production in India especially in Northern India (Haldhar et al. 2013; Haldhar et al. 2018). In light of above facts, attempts to integrate the promising technologies into operational IPM programme have been made in the present study for management of stone weevil. Continuous and indiscriminate use of chemical insecticides found to be ecologically unsafe and resulted in accumulation of pesticide residue on fruits. Therefore, it has become necessary to evaluate the new IPM modules for maximum reduction in stone weevil with least or no ill-effects on plant, consumer and environment. Keeping this in back drop, an attempt was made to formulate a sound management programme with organic IPM modules.

\section{Materials and Methods}

Field experiments were conducted at experimental farm of Central Institute for Arid Horticulture (CIAH), Bikaner (at $28^{\circ} 06^{\prime} \mathrm{N}$ latitude, $73^{\circ} 21^{\prime} \mathrm{E}$ longitude and altitude of $234.84 \mathrm{~m}$ above sea level) to evaluate the effectiveness of an organic IPM module against ber stone weevil in planted field with a spacing of 6 x 6 m during 2015-16 and 201617. All the recommended agronomic practices (e.g. weeding, fertilization, hoeing, etc.) were performed equally in each experimental plant. Twenty fruit were randomly selected in each of 4 replicates and average incidence was calculated as the per cent of fruit infested with A. himalayanus during 2015-16 and 2016-17. The infested fruits were sorted and the percent fruit infestation was calculated. The yield of fruit per plant was taken from all picking stages of ber crop. The avoidable loss and increase in fruit yield over control was calculated for each treatment by the following formula.

Avoidable loss $\%=\quad \begin{gathered}\text { Highest yield in treated plot }- \text { Yield in the treatment } \\ \ldots \ldots \ldots \ldots \ldots \ldots \ldots \ldots \ldots \ldots \ldots \ldots \ldots \ldots \ldots \ldots \ldots \ldots \ldots \ldots \ldots \ldots \ldots \ldots \ldots \ldots \ldots \ldots \ldots \ldots \\ \text { Highest yield in treated plot }\end{gathered}$




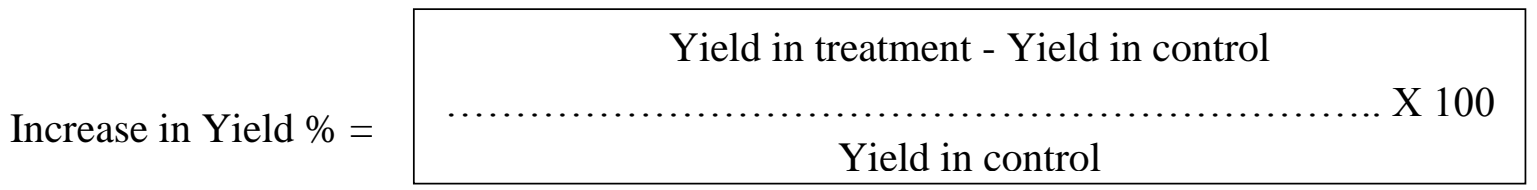

The formulae do not give the exact losses/ increase in yield because even in the treatment some damage occurs. However, this is considered to be the most feasible method for working out the percentage loss due to the insect pests in any treatment (Pradhan, 1964)

\section{Details of models}

MODULE-I: Farmer's practices/

\section{Conventional I}

a. Spray of Monocrotophos 36 SL @ $2 \mathrm{ml}$ per litre of water in October month

b. Two spray of Dimethoate 30 EC @ $2 \mathrm{ml}$ per litre of water in December month

\section{MODULE-II: Organic IPM}

a. Moderately Resistant genotype (Umran)

b. Deep summer ploughing after pruning of plants

c. Neem oil spray @ $5 \mathrm{ml}$ per litre of water in October month

d. Hand picking of damaged fruit and adult in November month

e. Spray of spinosad 46 SC @ $0.4 \mathrm{ml}$ per litre of water in December month

\section{MODULE-III: Conventional IPM}

a. Moderately Resistant genotype (Umran)

b. Spray of NSKE 5\% in October month

c. Spray of Dimethoate 30 EC @ 2 ml per litre of water in December month

\section{MODULE-IV: Conventional II}

a. Spray of Monocrotophos $36 \mathrm{SL}$ @ $2 \mathrm{ml}$ per litre of water in October month

b. Spray of NSKE 5\% in November month

c. Spray of Dimethoate 30 EC @ 2 ml per litre of water in December month
MODULE-V: No treatment/Control

Statistical analysis

Square root and angular transformations was used to achieve normality in the data before analysis (Steel et al. 1997), but untransformed means are presented in tables. Yield and stone weevil populations were compared among programs through oneway ANOVAs followed Tukey's honestly significant difference (HSD) tests for multiple comparisons at $P=0.05$. All treatments were performed in SPSS 16 software (O'Connor 2000).

\section{Results and Discussion}

Consequent to sole reliance and continuous usage of synthetic insecticides, not only control measures have lost their efficacy but also becoming economically non-viable. In this background, the results for different modules involving ecofriendly tools with minimal toxicant usage were carefully designed and verified in comparison with untreated control are presented here. A significant difference in stone weevil damage percent was observed under the different modules $(P<0.05)$. The pooled results showed that the organic IPM module-II registered had significantly lower stone weevil damage (12.04 percent in retained fruit \& 15.04 percent in dropped fruit) followed by module-I/ Farmer's practices/Conventional (21.26 percent in retained fruit \& 26.15 percent in dropped fruit). The highest stone weevil damage was observed for the control 
(49.23 percent in retained fruit \& 54.91 percent in dropped fruit) (Table $1 \&$ Figure 1). Effectiveness of organic amendments viz., neem cake and vermicompost besides neem derivatives against sucking pests has been documented by various workers (Varghese \& Giraddi, 2005; Haldhar et al. 2014), which lend support to the present findings. Singh et al. (2012) revealed that module (M1) proved be the most effective treatment against shoot and fruit borer, Earias vittella F., yellow vein mosaic virus vector, Bemisia tabaci (Genn.) and red spider mite, Tetranychus cinnabarinus (Boisd.) in which lowest incidence was recorded as compared to other IPM modules. The module M1 comprised of hand picking and destruction of infested leaves, shoots and fruits, seed treatment with imidacloprid, application of indoxacarb, thiomethoxam, hexythiazox, deep summer ploughing and use of neem cake @ 250 kg/ha before sowing was the most effective. Haldhar et al. (2014) resulted the organic IPM moduleIII comprised of growing resistant genotype (RM-50), spray of neem oil at 20 DAS, installation of pheromone trap (10/ hectare) at 42 DAS, spray of tumba fruit extract (TFE $5 \%$ ) at 50 DAS and spray of spinosad $46 \mathrm{SC}$ at 60 DAS was the most effective. The Table 1. Incidence of stone weevil (Aubeus himalayanus) on plant in different management modules of ber crop

\begin{tabular}{lcccccc}
\hline Treatments & \multicolumn{3}{c}{ Percent of stone weevil damage in } & \multicolumn{3}{c}{ Percent of stone weevil damage in } \\
& \multicolumn{3}{c}{ retained fruit } & \multicolumn{3}{c}{$\begin{array}{c}\text { dropped fruit } \\
\end{array}$} \\
& $2015-16$ & $2016-17$ & Pooled & $2015-16$ & $2016-17$ & Pooled \\
\hline \multirow{2}{*}{ Module-I } & 21.38 & 21.13 & 21.26 & 26.25 & 26.05 & 26.15 \\
& $(27.45)^{*}$ & $(27.27)$ & $(27.36)$ & $(30.69)$ & $(30.56)$ & $(30.63)$ \\
Module-II & 12.15 & 11.93 & 12.04 & 15.13 & 14.95 & 15.04 \\
& $(20.30)$ & $(20.10)$ & $(20.15)$ & $(22.86)$ & $(22.72)$ & $(22.79)$
\end{tabular}

conventional I (farmer's practices) was the second most effective system against major pests during both years. Pandey et al. (2016) showed that the IPM program provided 59.12, 57.12, 43.88, 55.98, 52.67, 49.41 and 52.24 \% reduction in white-grub, cut worm, cabbage butterfly, DBM, aphids, tobacco caterpillar, painted bug infestation, respectively, as compared to non-IPM practiced fields. Similarly, there was 52.15, 52.94 and $49.41 \%$ control of damping-off, black leg and white blight or head rot diseases, respectively, over non-IPM practice. Analysis of cost benefit ratio of IPM practice revealed that there was $58.88 \%$ increase in yield with net return of Rs. 65.59 thousand per ha over non-IPM practiced field. The B: C ratio of IPM practice field was 2.19. Nathan et al. (2004) recorded that combination of neem seed kernel extract and Bacillus thuringiensis were effective in controlling the leaf folder $C$. medinalis. Spinosad $45 \mathrm{SC}$ is a biological product from actinomycetes Saccharopolyspora spinosa was also effective in controlling rice leaf folder. Nalini et al. (2008), Karthikeyan et al. (2008), Suresh et al. (2011) and Haldhar et al. (2021) reported that application of spinosad 2.5 SC was effective against rice leaf folder. 


\begin{tabular}{lcccccc}
\hline & & & & & & \\
Module-III & 38.88 & 38.65 & 38.77 & 43.50 & 43.30 & 43.40 \\
& $(38.53)$ & $(38.40)$ & $(38.47)$ & $(41.23)$ & $(41.11)$ & $(41.17)$ \\
Module-IV & 31.48 & 31.33 & 31.41 & 33.08 & 32.93 & 33.01 \\
& $(34.09)$ & $(33.99)$ & $(34.04)$ & $(35.03)$ & $(34.94)$ & $(34.99)$ \\
\multirow{2}{*}{ Control } & 49.33 & 49.13 & 49.23 & 55.08 & 54.73 & 54.91 \\
& $(44.59)$ & $(44.48)$ & $(44.54)$ & $(47.94)$ & $(47.74)$ & $(47.84)$ \\
\hline SEm \pm & 0.96 & 0.92 & 0.94 & 0.97 & 0.99 & 0.98 \\
LSD $(\mathrm{P}=0.05)$ & 3.00 & 3.03 & 3.02 & 3.02 & 3.07 & 3.05 \\
\hline
\end{tabular}

*Values in parenthesis are angular-transformed

Value following different letter are significantly different using Tukey's HSD test

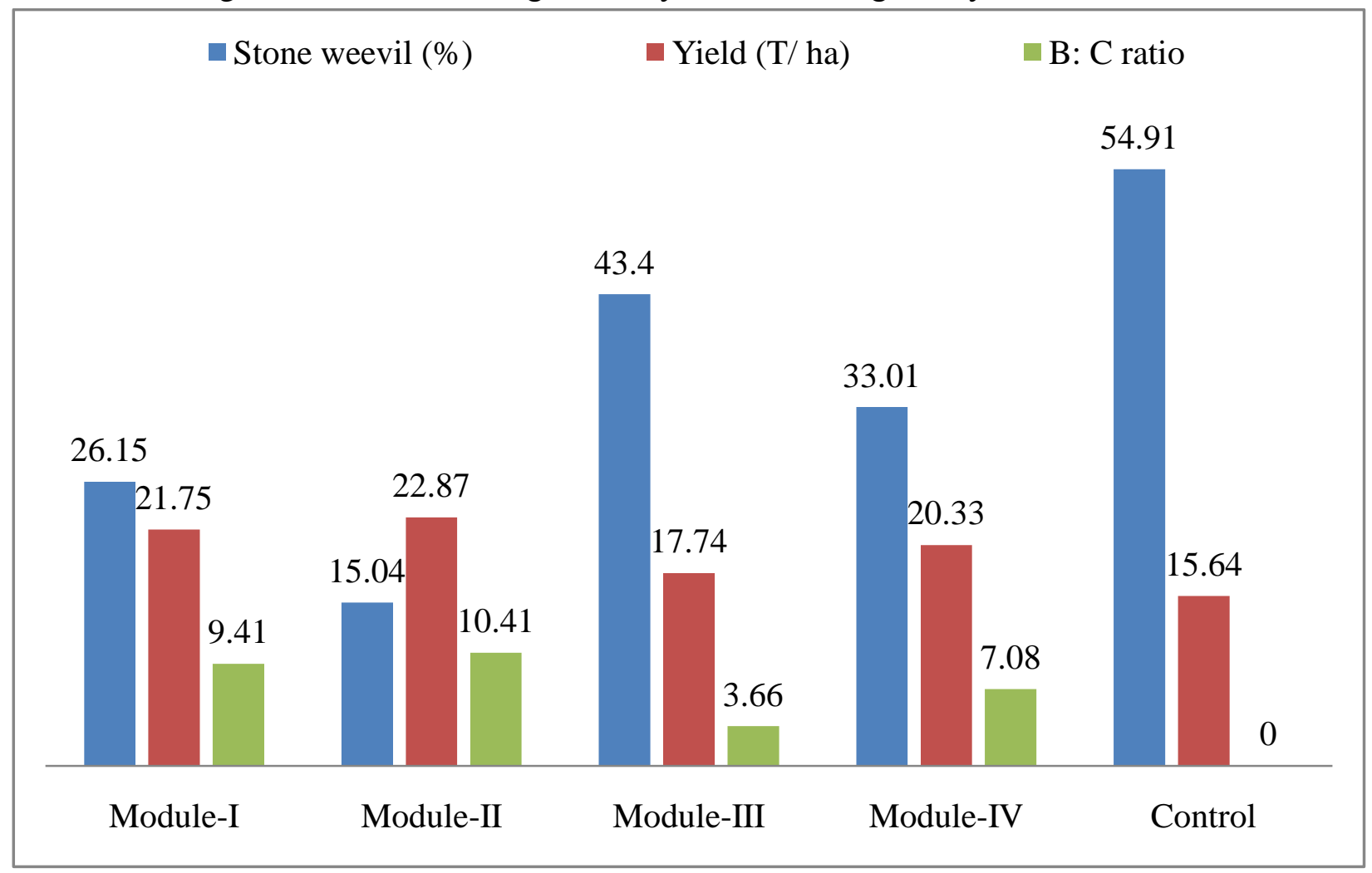

Figure 1. Association of stone weevil, yield and B: C ratio in different management modules of ber crop

The marketable yield of berfruits q/ha)> module-III (177.39 q/ha)> control differed significantly under different modules during both the years as well as pooled results $(P<0.05)$ (Table 2, 3 and Figure 1). The fresh fruit yield of ber observed in the different programs decreased in the following order: organic IPM module-II (228.69 q/ha)> module-I (217.54 q/ha)> module-IV (203.33 $(156.43 \mathrm{q} / \mathrm{ha})$ in pooled results. The same trend was observed during both the years. The percent avoidable losses were lowest in Module-II followed by Module-I and maximum was recorded in control. Percent yield increase over control was maximum in Module-II (46.19\%) followed by Module-I 
(39.07\%) and minimum was recorded in Module-III (14.40\%) followed by Module-IV $(29.98 \%)$. It can be inferred from the results that organic IPM module-II was highly effective and gave higher yield of marketable ber fruits. The higher Benefit-Cost Ratio was obtained in the organic IPM module-II (10.41:1) followed by module-I (9.41:1), and lowest BCR was obtained in module-III (3.66:1).

Table 2. Economic yield in different management modules of ber crop

\begin{tabular}{lcccccc}
\hline Treatments & \multicolumn{3}{c}{ Yield in Kg per plant } & \multicolumn{3}{c}{ Yield in quintal per hectare } \\
& $2015-16$ & $2016-17$ & Pooled & $2015-16$ & $2016-17$ & Pooled \\
\hline Module-I & 77.60 & 78.90 & 78.25 & 215.73 & 2.19 .34 & 217.54 \\
& $(62.38)^{*}$ & $(63.42)$ & $(62.90)$ & & & \\
Module-II & 82.01 & 82.50 & 82.26 & 227.99 & 229.35 & 228.69 \\
& $(65.79)$ & $(66.24)$ & $(66.02)$ & & & \\
Module-III & 63.48 & 64.13 & 63.81 & 176.47 & 178.28 & 177.39 \\
& $(52.94)$ & $(53.34)$ & $(53.14)$ & & & \\
Module-IV & 72.85 & 73.43 & 73.14 & 202.52 & 204.14 & 203.33 \\
& $(58.83)$ & $(59.20)$ & $(59.02)$ & & & \\
Control & 55.98 & 56.55 & 56.27 & 155.62 & 157.21 & 156.43 \\
& $(48.45)$ & $(48.79)$ & $(48.62)$ & & & \\
\hline SEm \pm & 1.51 & 1.56 & 1.54 & - & - & - \\
LSD $(\mathrm{P}=0.05)$ & 4.70 & 4.85 & 4.78 & - & - & - \\
\hline
\end{tabular}

*Values in parenthesis are angular-transformed

Value following different letter are significantly different using Tukey's HSD test

Table 3. Economics and assessment of losses caused by stone weevil in ber in arid region of India

\begin{tabular}{lcccccccc}
\hline Treatments & $\begin{array}{c}\text { Yield } \\
\text { (q/ha) }\end{array}$ & $\begin{array}{c}\text { Total } \\
\text { avoida } \\
\text { ble } \\
\text { losses } \\
\text { (q/ha) }\end{array}$ & $\begin{array}{c}\text { Percent } \\
\text { avoidabl } \\
\text { e losses }\end{array}$ & $\begin{array}{c}\text { Yield } \\
\text { increase } \\
\text { over } \\
\text { control } \\
(\mathrm{q} / \mathrm{ha})\end{array}$ & $\begin{array}{c}\text { Percent } \\
\text { yield } \\
\text { increase } \\
\text { over } \\
\text { control }\end{array}$ & $\begin{array}{c}\text { Return } \\
\text { of } \\
\text { increase } \\
\text { d yield } \\
(\mathrm{Rs}) * *\end{array}$ & $\begin{array}{c}\text { Total } \\
\text { cost of } \\
\text { module } \\
\text { expenditu } \\
\text { re }\end{array}$ & $\begin{array}{c}\text { B:C } \\
\text { ratio }\end{array}$ \\
\hline Module-I & 217.54 & 11.15 & 04.88 & 61.11 & 39.07 & 58605 & 6226 & 09.41 \\
Module-II & $228.69 *$ & 00.00 & 0.00 & 72.26 & 46.19 & 69285 & 6844 & 10.41 \\
Module-III & 177.39 & 51.30 & 22.43 & 20.96 & 13.40 & 20100 & 5488 & 03.66 \\
Module-IV & 203.33 & 25.36 & 11.09 & 46.90 & 29.98 & 44970 & 6352 & 07.08 \\
Control & 156.43 & 72.26 & 31.60 & 00.00 & 00.00 & 00.00 & 00.00 & 00.00 \\
\hline$*$
\end{tabular}

* Highest yield in the module plots

** Cost of muskmelon fruit in summer season was 1500 Rs per qt.

*** It includes module and labour charges 
According to Gundannavar et al. (2007) a significant higher yield (5.13 q/ha) was recorded in module-I which was at par with module-II (5.04) and module-III (4.91). However, least yield (4.29 q/ha) was registered in module IV for controlling insect pests of chilli. Praveen \& Dhandapani (2001) recorded cost benefit ratio of 1:2.60 when $C$. carnea+Econeem was applied on okra against major insect pests. Das et al. (2001) recorded the highest cost benefit ratio from application of acephate (1:58) followed by imidacloprid (1:4.63) in okra. Shukla et al. (1996) found fenvalerate highly cost effective with a cost: benefit ratio of 1:10.3. Singh \& Kumar (2003) found neem products effective against jassid on okra and on the basis of cost: benefit ratio, neem seed kernel extract (3\%) ranked first $(1: 10.7)$ followed by endosulfan (1:10.1). Haldhar et al. (2014) observed that benefitcost ratio of the tested muskmelon production systems in the control of insect-pests decreased in the following order: module-III (B: $\mathrm{C}$ ratio 8.80:1)> module-I (B: $\mathrm{C}$ ratio 7.74:1)> module-IV (B: $\mathrm{C}$ ratio 6.60:1)> module-II (B: $\mathrm{C}$ ratio 3.56:1). In summary, the reduction of stone weevil and increased yield of ber crop could be due to the organic IPM module-II having moderately resistant genotype (Umran), deep summer ploughing after pruning of plants, neem oil spray @ $5 \mathrm{ml}$ per litre of water in October month, hand picking of damaged fruit and adult in November month and spray of spinosad 46 SC @ $0.4 \mathrm{ml}$ per litre of water in December month. In future the organic IPM module-II will be economic and therefore, can be used to reduction of stone weevil, environmental safety and increased yield of ber crop.

\section{Acknowledgments}

The authors are thankful to Director, ICAR-Central Institute for Arid Horticulture, Bikaner, India, for providing facilities and advice required for experimentation and to $\mathrm{R}$. Swaminathan, Professor, Department of Entomology, MPUAT, Udaipur, India and Majeet Singh, Professor, SKRAU, Bikaner, India for critical discussion and suggestions.

\section{References}

Bakhshi JC \& Singh P. 1974. The ber - a good choice for semi-arid and marginal soils. Indian Horticulture, 19: 27-30.

Balikai RA. 2009. Seasonal occurrence of ber fruit weevil, Aubeus himalayanus Voss in India. Acta Horticulture, 840: 461474.

Balikai RA, Kotikal YK \& Prasanna PM. 2013. Global scenario of insect and non-insect pests of jujube and their management options. Acta Horticulture, 993: 253-277.

Das SN, Subhraj R, Chatterjee ML \& Ray S. 2001. Bioefficacy, yield benefit and cost effectivety of some new molecules against okra fruit borer, Earias vittella (F) (Noctidae: Lepidoptera). Journal of Interacad, 5: 346-351.

Gundannavar KP, Giraddi RS, Kulkarni KA \& Awaknavar JS. 2007. Development of integrated pest management modules for chilli pests. Karnataka Journal of Agriculture Science, 20: 757-760.

Haldhar SM, Choudhary BR, Bhargava R \& Sharma SK. 2014. Development of an organic integrated pest management (IPM) module against insect-pests of muskmelon in arid region of Rajasthan, India. Journal of 
Experimental Biology and Agricultural Sciences, 2(1): 19-24.

Haldhar SM, Singh AK, Kumar K \& Sarolia DK. 2018. Antixenotic and allelochemical resistance traits of ber (Ziziphus mauritiana) against stone weevil, Aubeus himalayanus in hot arid region of India. Indian Journal of Arid Horticulture, 13: 50-58.

Haldhar SM, Singh AK, Singh D \& Sarolia D K. 2021. Evaluation of different IPM modules against ber stone weevil, Aubeus himalayanus in hot arid region of India. Published in National Conference on Priorities in Crop Protection for Sustainable Agriculture organized by CAU, Imphal during 1618 March 2021. Pp. 205-206.

Haldhar SM, Deshwal HL, Jat GC, Berwal MK \& Singh, D. 2016. Pest scenario of ber (Ziziphus mauritianaLam.) in arid regions of Rajasthan, a review. Journal of Agriculture and Ecology, 1: 10-21.

Haldhar SM, Karuppaiah V, Sharma SK \& Singh D. 2012. Insect-pests of ber (Ziziphus mauritiana Lam.) as influenced by abiotic factors in arid region of Rajasthan. Global conference on "Horticulture for food, nutrition and livelihood options" organised by ASM foundation, New Delhi and OUAT, Bhubaneswar. Odisha during 27-31, May, 2012.

Haldhar SM, Sharma SK, Bhargava R, Singh RS, Sharma BD \& Singh D. 2013. Insect pests of arid fruit crops, practical manual for field identification and damage symptoms. CIAH/ Tech./ Pub. No. 42 pp 1-53.

Karthikeyan K, Purushothaman, SM \& Smitha R. 2008. Effect of spinosad against major insect pests and natural enemies in rice ecosystem. Journal of Biological Control, 22: 315-320.

Karuppaiah V, More TA \& Bagle BG. 2010. A record of stone weevil (Aubeus himalayanus) (Curculionidae: Coleoptera) on ber in hot arid region of Bikaner, Rajasthan. Karanataka Journal of Agriculture Science, 23: 180-181.

Kavitha Z \& Savithri P. 2002. Documentation of insect pests on ber. South Indian Horticulture, 50: 223-225.

Morton J. 1987. Fruits of warm climates. Julia F. Morton, Miami, FL. p.272-275.

Nalini R, Shanthi M, Rajavel DS \& Murali Baskaran RK. 2008. Bio-efficacy of new insecticide molecules on rice leaf folder Marasmia exigua (Butler). Pestology, 32: 13-15.

Nathan SS, Chung PG \& Murugan K. 2004. Effect of botanicals and bacterial toxin on the gut enzyme of Cnaphalocrocis medinalis. Phytoparasitica, 32: 433443.

O'Connor BP. 2000. SPSS and SAS programs for determining the number of components using parallel analysis and Velicer's MAP test. Behavior Research Methods, Instrumentation and Computer, 32: 396-402.

Pandey AK, Kumar B \& Dev C. 2016. Validation of IPM module against major insect-pests and diseases of cabbage in mid-hills of Uttarakhand. 
Journal of Hill Agriculture, 7(1): 96101.

Pradhan S. 1964. Assessment of losses caused by insect pests of crop and estimation of insect population. Entomology in India, New Delhi, pp. 17-58.

Praveen PM \& Dhandapani N. 2001. Ecofriendly management of major pests of okra (Abelmoschus esculentus (L.) Moench). Journal of Vegetable Crop Production, 7: 3-12.

Shukla A, Pathak SC \& Agrawal RK. 1996. Efficacy economics of some insecticides and plant products against the infestation of okra shoot and fruit borer, Earias vittella (Fab.). Crop Research, 12: 367-373.

Singh AK \& Kumar M. 2003. Efficacy and economics of neem based products against cotton jassid, Amrasca biguttulla Ishida in okra. Crop Research, 26: 271274.

Singh SS, Rai Mayank K, Dwivedi SK \& Kumar P. 2012. Validation of IPM modules against major pests of okra in
Dehradun (Uttarakhand). Indian Journal of Entomology, 74: 375-378.

Singh MP. 2008. Managing menace of insect pests on ber. Indian Horticulture, 53: 31-32.

Steel RGD, Torrie JH \& Dickey DA. 1997. Analysis of variance II: multiway classifications. In: Steel RGD, Torrie JH, Dickey DA, (Ed), Principles and Procedures of Statistics: A Biometrical Approach (third ed.), WCB/McGrawHill, USA,pp 204-252.

Suresh DK, Hegde M, Nayak GV, Vastrad AS, Hugar PS \& Basavanagoud K. 2011. Evaluation of insecticides and biorational against yellow stem borer and leaf folder in rice crop. Karnataka Journal of Agriculture Science, 24: 244246.

Varghese TS \& Giraddi RS. 2005. Integration of neem cake in the plant protection schedule for thrips and mite management in chilli (cv. Byadagi). Karnataka Journal of Agricultural Science, 18: 154-156. 